\author{
Krzysztof SORNEK ${ }^{1}$ \\ Mariusz FILIPOWICZ ${ }^{2}$ \\ Krzysztof IZDEBSKI ${ }^{3}$
}

\title{
BADANIE WYBRANYCH PARAMETRÓW PRACY PROTOTYPOWEGO SYSTEMU CHP MAŁEJ SKALI Z KOTŁEM NA BIOMASE,
}

\begin{abstract}
Niniejszy artykuł przedstawia możliwości wykorzystania kotłów na biomasę do budowy systemów skojarzonego wytwarzania ciepła i energii elektrycznej w rozwiązaniach małej i mikro skali. Podstawowym celem prowadzonych badań jest konstrukcja prototypowej jednostki kogeneracyjnej, mogącej współpracować z kotłami na słomę i inną biomasę o mocy cieplnej z zakresu $35-500 \mathrm{~kW}_{\text {th }}$, stworzenie algorytmu sterowania, a także opracowanie wytycznych do wykonania dedykowanej konstrukcji kotła. W tym celu prowadzone są pomiary wybranych parametrów pracy pierwszej wersji systemu kogeneracyjnego, w tym pomiary wielkości ciepła wysokotemperaturowego, możliwego do uzyskania przy użyciu specjalnie zaprojektowanego wymiennika olejowego umieszczonego w komorze dopalania kotła, a także pomiary wielkości ciepła możliwego do odebrania przez obieg czynnika niskowrzącego. W pierwszym etapie badań rozruchowych instalacji, zamiast czynnika niskowrzącego, stosowana jest woda oraz prostej konstrukcji silnik parowy, napędzany parą wodną, wytworzoną w płaszczu wymiennika płaszczowo-rurowego, wskutek odebrania ciepła od gorącego oleju. W dalszym etapie prac zastosowany zostanie specjalnie zmodyfikowany silnik, który pozwoli zastąpić drogą mikroturbinę parową o stosunkowo niskiej sprawności. Wyniki wstępnych badań pozwalają określić charakter pracy instalacji w zależności od jej konkretnej konfiguracji, a jednocześnie potwierdzają zasadność prowadzenia dalszych prac badawczo-rozwojowych, które pozwolą na uzyskanie finalnego produktu, dedykowanego do szerokiego spektrum zastosować w małej i mikro skali.
\end{abstract}

Słowa kluczowe: odnawialne źródła energii, biomasa, kogeneracja, energetyka rozproszona, mikroźródła

\footnotetext{
${ }^{1}$ Autor do korespondencji: Krzysztof Sornek, AGH Akademia Górniczo-Hutnicza, Wydział Energetyki i Paliw, Al. A. Mickiewicza 30, 30-059 Kraków, tel. 600313 157, e-mail: krzysztof.sornek@agh.edu.pl

2 Mariusz Filipowcz, AGH Akademia Górniczo-Hutnicza, Wydział Energetyki i Paliw, Al. A. Mickiewicza 30, 30-059 Kraków, tel. 1261750 94, e-mail: mariusz.filipowicz@agh.edu.pl

${ }^{3}$ Krzysztof Izdebski, AGH Akademia Górniczo-Hutnicza, Wydział Energetyki i Paliw, Al. A. Mickiewicza 30,30-059 Kraków, krzysztof.izdebski90@gmail.com
} 


\section{Wprowadzenie do zagadnienia systemów CHP}

Systemy skojarzonego wytwarzania ciepła i energii elektrycznej (w skrócie CHP $-\mathrm{z}$ ang. Combined Heat and Power) w zdecydowanej większości stosowane były do niedawna w rozwiązaniach energetyki zawodowej. Podstawowymi urządzeniami układów kogeneracyjnych występujących w tym obszarze są turbiny parowe przeciwprężne i upustowo-kondensacyjne (pracujące w obiegu Rankine'a) oraz turbiny gazowe (pracujące w obiegu Braytona). Obecnie dąży się do stosowania układów CHP także w skali lokalnej, jako jednostek wytwórczych energii elektrycznej z możliwością wytwarzania ciepła w systemach energetyki rozproszonej. Ze względu na moc elektryczną, podział urządzeń energetyki rozproszonej jest następujący:

- duża energetyka rozproszona (50 $\mathrm{MW}_{\mathrm{el}}-100$ lub $\left.150 \mathrm{MW}_{\mathrm{el}}\right)$;

- średnia energetyka rozproszona $\left(5 \mathrm{MW}_{\mathrm{el}}-50 \mathrm{MW}_{\mathrm{el}}\right)$;

- mała energetyka rozproszona $\left(5 \mathrm{~kW}_{\mathrm{el}}-5 \mathrm{MW}_{\mathrm{el}}\right)$;

- mikroenergetyka rozproszona (do $5 \mathrm{~kW}_{\mathrm{el}}$ ).

W systemach rozproszonych stosowane są różne technologie wytwarzania ciepła i energii elektrycznej, pokrótce opisane niżej (skupiono się wyłącznie na jednostkach skali małej i mikro). Wyprodukowana w ten sposób energia zaspokaja w pierwszej kolejności potrzeby wytwórcy (np. budynków mieszkalnych, gospodarstw rolnych, obiektów użyteczności publicznej itp.), a nadwyżki energii trafiają do lokalnych rozdzielczych sieci elektroenergetycznych (w przypadku energii elektrycznej) lub lokalnych sieci ciepłowniczych (w przypadku ciepła). W ten sposób unika się szeregu wad energetyki scentralizowanej.

\subsection{Układy kogeneracyjne mikro i małej skali}

Aktualnie dostępne rozwiązania układów kogeneracyjnych mikro i małej skali obejmują urządzenia oparte na wykorzystaniu technologii silników spalania wewnętrznego (silnik Diesla i Otto), silników spalania zewnętrznego (silnik Stirlinga), turbin parowych, turbin i mikroturbin gazowych oraz ogniw paliwowych.

Wymienione wyżej rozwiązania na obecnym etapie tylko częściowo wykorzystywane są w rozwiązaniach komercyjnych (dostępne urządzenia zasilane są głównie gazem ziemnym i olejem napędowym), natomiast znaczna część znajduje się wciąż na etapie prac badawczych i aplikacyjnych. Uwzględniając urządzenia posiadające możliwość współpracy z zewnętrznymi źródłami ciepła, opartymi o wykorzystanie odnawialnych źródeł energii (np. energii biomasy lub energii promieniowania słonecznego) dużym potencjałem odznaczają się układy z silnikami Stirlinga oraz turbinami i silnikami parowymi. W perspektywie najbliższych lat rozwój technologii powinien umożliwić także wykorzystanie ogniw paliwowych w systemach mikro i małej skali. 


\subsection{Kotły na biomasę jako źródło ciepła dla systemów kogeneracyjnych}

Zgodnie z założeniami Komisji Europejskiej, przedstawionymi w dokumencie EU Energy, Transport and GHG Emissions Trends to 2050 [1], ogólny udział odnawialnych źródeł energii w wytwarzaniu energii elektrycznej osiągnie w 2050 roku poziom 50\%. Wzrost udziału OZE w produkcji energii elektrycznej związany jest $\mathrm{w}$ dużej mierze $\mathrm{z}$ przewidywanym dynamicznym rozwojem systemów energetyki rozproszonej, w tym sieci smart grid. W tego typu rozwiązaniach, energia elektryczna będzie wytwarzana m.in. w układach kogeneracyjnych, działających na zasadzie organicznego obiegu Rankine'a (ORC). Odparowanie czynnika roboczego, którego pary napędzają turbinę parową (silnik parowy) połączoną z generatorem prądotwórczym, będzie mogło następować przy wykorzystaniu ciepła generowanego w kotłach na biomasę. Przewidywany udział biomasy w lokalnych systemach CHP oraz w ogrzewaniu sieciowym i kotłowniach domowych, na przestrzeni kolejnych lat do roku 2050, pokazany został na rysunku 1.
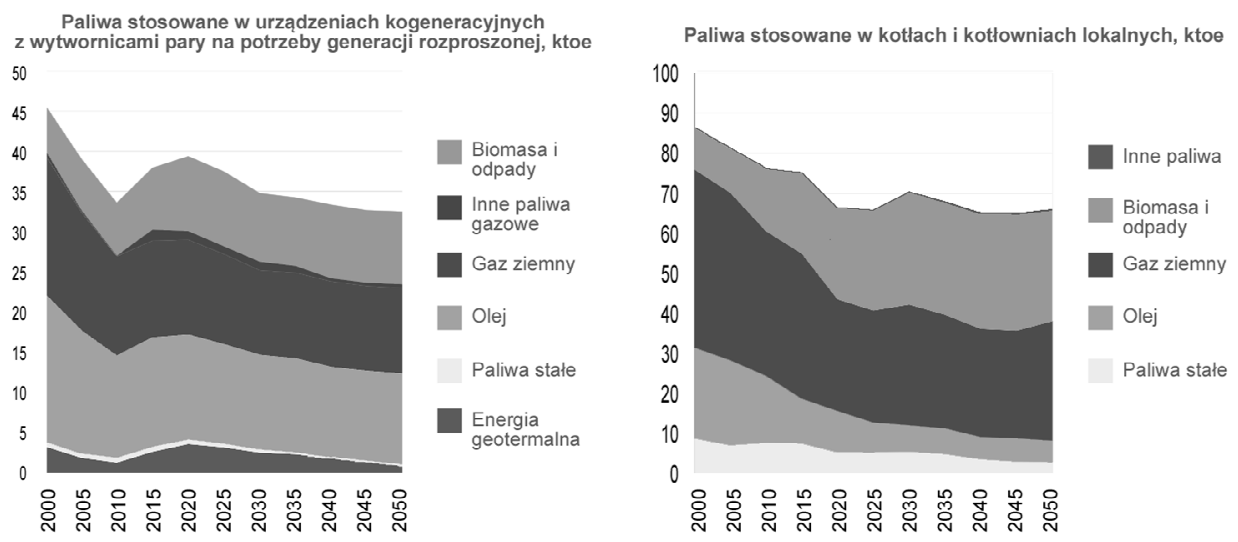

Rys. 1. Przewidywany udział biomasy w lokalnych systemach CHP oraz w systemach grzewczych (opr. własne na podst. [1])

Fig. 1. Predicted biomass share in local CHP systems and heating systems (own work based on [1])

Zastosowanie układów kogeneracyjnych z kotłem na biomasę jest możliwe zarówno w przypadku budynków mieszkalnych i użyteczności publicznej, jak również w przypadku gospodarstw rolnych. Te ostatnie borykają się bardzo często z problemem braku dostępu do sieci elektroenergetycznej, co powoduje konieczność stosowania drogich w eksploatacji urządzeń prądotwórczych z silnikami spalania wewnętrznego, napędzanych głównie olejem napędowym. Zastosowanie $\mathrm{w}$ takich przypadkach układów kogeneracyjnych z kotłem na biomasę pozwoli osiągnąć całkowitą lub częściową niezależność energetyczną, gdyż spalanie paliwa dostępnego na obszarze gospodarstwa pozwoli na zasilenie urządzeń wytwarzających energię elektryczną. 


\section{Konstrukcja prototypowego systemu kogeneracyjnego}

\subsection{Typowe układy ORC małej i mikro skali}

Budowa typowego układu ORC z kotłem na biomasę, dedykowanego do rozwiązań małej lub mikro skali, obejmuje takie elementy, jak: kocioł grzewczy, obieg pośredni oleju termalnego (odbierającego ciepło od gorących spalin i przekazującego je do czynnika niskowrzącego), parownik, turbina parowa (lub silnik parowy), generator energii elektrycznej, skraplacz oraz pompy obiegowe oleju termalnego i czynnika niskowrzącego. Sprawność wytwarzania energii elektrycznej w typowym układzie ORC osiąga poziom ok. 10-20\%.

Opisana konstrukcja nie jest pozbawiona wad. Największa trudność związana jest $\mathrm{z}$ budową mikroturbiny parowej o mocy kilku- lub kilkunastu $\mathrm{kW}_{\mathrm{el}}$, której parametrów konstrukcyjnych nie można wprost przenieść z rozwiązań dużej skali. Dostępne aktualnie rozwiązania turbin (znajdujące się w fazie aplikacyjnej) charakteryzują się stosunkowo niską sprawnością i wysoką ceną.

Dodatkowych badań wymaga także kwestia współpracy układu prądotwórczego z kotłem na biomasę, szczególnie w zakresie opracowania optymalnego systemu odbioru ciepła wysokotemperaturowego oraz dopasowania parametrów pracy kotła zarówno do potrzeb grzewczych, potrzeb układu prądotwórczego, jak i wymagań w zakresie emisji dwutlenku węgla i pyłów do atmosfery.

\subsection{Konstrukcja prototypowego układu ORC}

Mając na uwadze niedogodności typowych układów ORC małej i mikro skali, a jednocześnie znając realne zapotrzebowanie na tego typu rozwiązania, podjęta została budowa układu skojarzonego wytwarzania ciepła i energii elektrycznej małej skali, opartego o wykorzystanie kotła na słomę i inną biomasę, przeznaczonego do zastosowania w gospodarstwach rolnych. Cel, jaki został postawiony to $\mathrm{w}$ pierwszej kolejności osiągnięcie niezależności energetycznej samego urządzenia kogeneracyjnego, a następnie częściowej lub całkowitej niezależności energetycznej gospodarstwa, w którym zostanie ono zastosowane.

W oparciu o wyniki badań parametrów pracy kotła wsadowego na słomę o mocy $180 \mathrm{~kW}$ ze spalaniem w systemie przeciwprądowym (w tym badań dynamiki zmian temperatury w komorze spalania pierwotnego i wtórnego kotła, w płaszczu wodnym oraz w obszarze czopucha kominowego [2]) opracowany został system odbioru ciepła wysokotemperaturowego do obiegu olejowego. W skład opracowanego systemu wchodzi specjalnej konstrukcji wymiennik olejowy, wykonany z rur stalowych o średnicy DN50, umieszczony w obszarze komory spalania wtórnego oraz połączony z resztą układu za pomocą króćców wyprowadzonych przez górne drzwi kotła. Obieg olejowy składa się z dwóch wymienników ciepła typu JAD, połączonych w taki sposób, że możliwa jest praca tylko jednego wymiennika lub dwóch połączonych szeregowo albo równolegle (przełączanie za pomocą zaworów trójdrogowych). Obieg oleju wymu- 
szany jest za pomoca pompy olejowej, sterowanej z poziomu falownika. Po stronie wtórnej wymienników typu JAD znajduje się obieg parowy, wyposażony w prototypowy silnik parowy małej mocy. Silnik ten powstał na bazie sprężarki tłokowej, dzięki czemu przy stosunkowo niedużym obniżeniu sprawności (w porównaniu do mikroturbiny parowej) możliwe jest znaczne obniżenie kosztów produkcji urządzenia. Oprócz silnika parowego, w skład prototypowego układu ORC wejdzie dedykowany skraplacz (połączony z obiegiem grzewczym) oraz ekonomizer [3]. Planowany do wykorzystania czynnik niskowrzący $3 \mathrm{M} \circledast$ Novec ${ }^{\circledR} 7000$ charakteryzuje się temperaturą wrzenia równą $34^{\circ} \mathrm{C}$ (przy ciśnieniu 1 bar), temperaturą krytyczną $165^{\circ} \mathrm{C}$ i ciśnieniem krytycznym 24,8 bar. Schemat uwzględniający obieg olejowy oraz część obiegu parowego (tymczasowo stosowana była woda) przedstawiony został na rysunku 2.

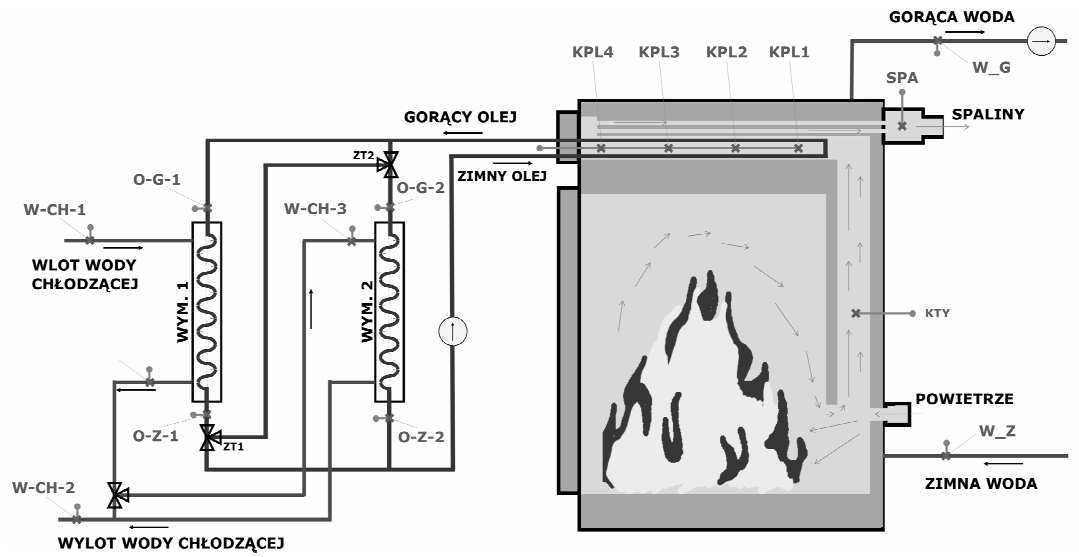

Rys. 2. Rozmieszczenie czujników temperatury w części olejowej i parowej układu kogeneracyjnego (opr. własne)

Fig. 2. Arrangement of temperature sensors in the oil and steam parts of cogeneration system (own work)

\section{Omówienie dotychczas otrzymanych wyników}

Wyniki przeprowadzonych dotychczas badań wstępnych (towarzyszących pierwszemu rozruchowi systemu) potwierdzają duży potencjał opracowywanego rozwiązania. Przedstawione poniżej wykresy obrazują przebieg zmian temperatury w wybranych punktach obiegu olejowego i wodnego, a także chwilowe wartości mocy grzewczej kotła, mocy obiegu olejowego oraz mocy obiegu wodnego w przypadku pracy pojedynczego wymiennika JAD, jak również połączenia szeregowego i równoległego dwóch wymienników. Sposób sterowania pracą kotła był identyczny w każdym z przypadków - po okresie rozpalenia paliwa, wentylator nadmuchowy ustawiany był na $100 \%$ swojej mocy i pracował tak aż do wypalenia wsadu. Momenty załączenie pomp obiegowych oleju i wody chłodzącej, zaznaczone zostały na wykresach. 


\subsection{Układ z 1 wymiennikiem ciepła typu JAD}

W pierwszym z rozważanych przypadków, układ olejowy pracował z wykorzystaniem tylko jednego wymiennika ciepła typu JAD. Przy spaleniu jednego wsadu paliwa o masie $65 \mathrm{~kg}$ (60 kg słomy oraz $5 \mathrm{~kg}$ papieru), osiągnięto temperaturę oleju na poziomie przekraczającym $150^{\circ} \mathrm{C}$ (przy czym w momencie gwałtownego wzrostu temperatury uruchomiona została na pełną moc pompa obiegowa oleju). Gwałtowny przyrost temperatury związany był ze sposobem rozprowadzenia ciepła w obiegu - gorący olej najpierw rozchodził się w górnych częściach układu, a dopiero po pewnym czasie trafiał na wymiennik JAD. W efekcie ok. 18 minuty procesu uzyskano chwilową wartość mocy układu olejowego na poziomie $60 \mathrm{~kW}$ (1/3 nominalnej mocy cieplnej kotła) oraz aż 50 $\mathrm{kW}$ mocy układu wodnego, chłodzącego część olejową. Temperatura wody chłodzącej osiągnęła ponad $40^{\circ} \mathrm{C}$ (pompa działała na pełnej mocy od początku). Przebiegi zmian temperatury oleju i wody chłodzącej oraz zmian mocy w poszczególnych częściach układu pokazane zostały na rysunku 3.
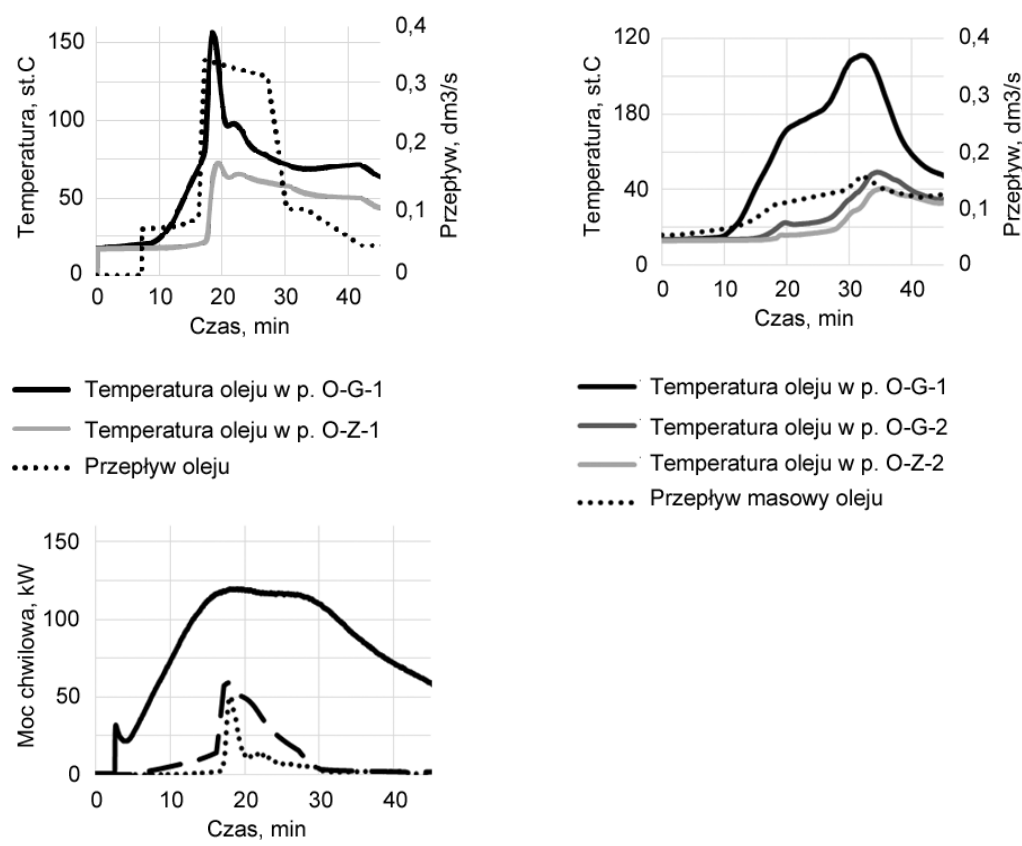

...... Przepływ masowy oleju

\footnotetext{
- Moc chwilowa kotła

- Moc chwilowa obiegu olejowego

..... Moc chwilowa obiegu wodnego
}

Rys. 3. Przebiegi zmian temperatury oleju i wody chłodzącej oraz zmian mocy w poszczególnych częściach układu Fig. 3. Oil temperature, cooling water temperature and power changes in different parts of the cogeneration system 


\subsection{Układ z 2 wymiennikami ciepła typu JAD (połączenie szeregowe)}

W drugim z rozważanych przypadków, układ olejowy pracował z wykorzystaniem dwóch wymienników ciepła typu JAD połączonych szeregowo, chłodzonych wodą w układzie współprądowym. W tej sytuacji widoczny jest znaczący spadek prędkości przepływu (a więc strumienia masowego) oleju, co znajduje odzwierciedlenie w przebiegu zmian temperatury i mocy chwilowej. Ze względu na sposób prowadzenia całego procesu (m.in. praca pompy obiegowej oleju włączona na $100 \%$ mocy po upływie 5 minut od rozpoczęcia procesu spalania, późniejsze włączenie pompy obiegowej wody chłodzącej), maksymalne wartości temperatury oleju i wody osiągane są w końcowej fazie procesu spalania. Mały załadunek paliwa (45 kg słomy o średniej wilgotności $12 \%$ oraz $5 \mathrm{~kg}$ papieru) spowodował, iż temperatura oleju na wyjściu z kotła osiągnęła zaledwie $110^{\circ} \mathrm{C}$, zaś na powrocie do kotła nie przekroczyła $50^{\circ} \mathrm{C}$. Maksymalna moc w układzie olejowym wynosi w tym przypadku ok. $25 \mathrm{~kW}$, a moc obiegu wodnego - ok. $15 \mathrm{~kW}$. Przebiegi zmian temperatury oleju i wody chłodzącej oraz zmian mocy w układzie pokazane zostały na rysunku 4 .
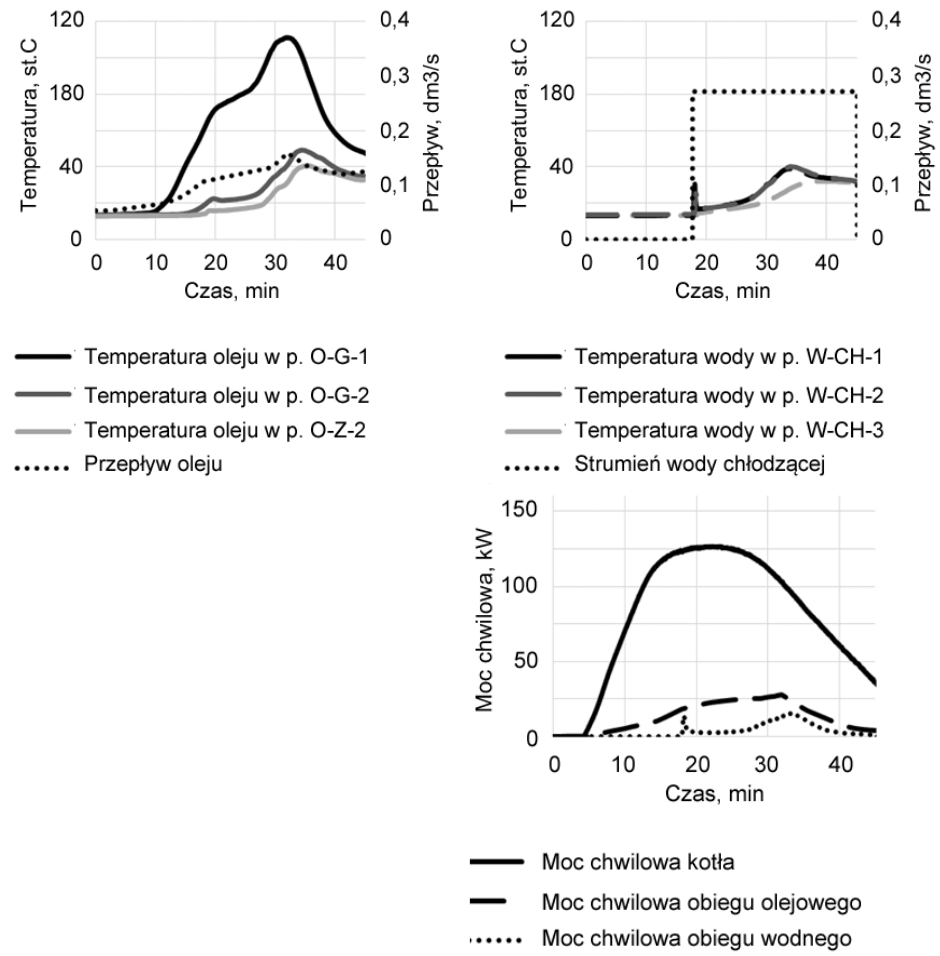

Rys. 4. Przebiegi zmian temperatury oleju i wody chłodzącej oraz zmian mocy w poszczególnych częściach układu Fig. 4. Oil temperature, cooling water temperature and power changes in different parts of the cogeneration system 


\subsection{Układ z 2 wymiennikami ciepła typu JAD (połączenie równoległe)}

W ostatnim z rozważanych przypadków, układ olejowy pracował z wykorzystaniem dwóch wymienników ciepła typu JAD połączonych równolegle. Badania przeprowadzono przy dwóch paleniach następujących zaraz po sobie. Maksymalna temperatura oleju osiągnęła pułap niespełna $120^{\circ} \mathrm{C}$ (na wyjściu $\mathrm{z}$ kotła podczas drugiego palenia), natomiast temperatura na powrocie do kotła utrzymywała się na poziomie ok. $80^{\circ} \mathrm{C}$. Ze względu na szeregowe połączenie wymienników po stronie chłodzonej, na wyjściu wymienników wystąpiła niewielka różnica temperatury oleju. Można zauważyć, że przy drugim paleniu temperatura oleju wzrosła o kilkanaście procent, co pozwala wysnuć wniosek, że kolejne palenia podniosłyby temperaturę proporcjonalnie wyżej. Przebieg zmian temperatury oleju i wody chłodzącej zobrazowany został na rysunku 5.
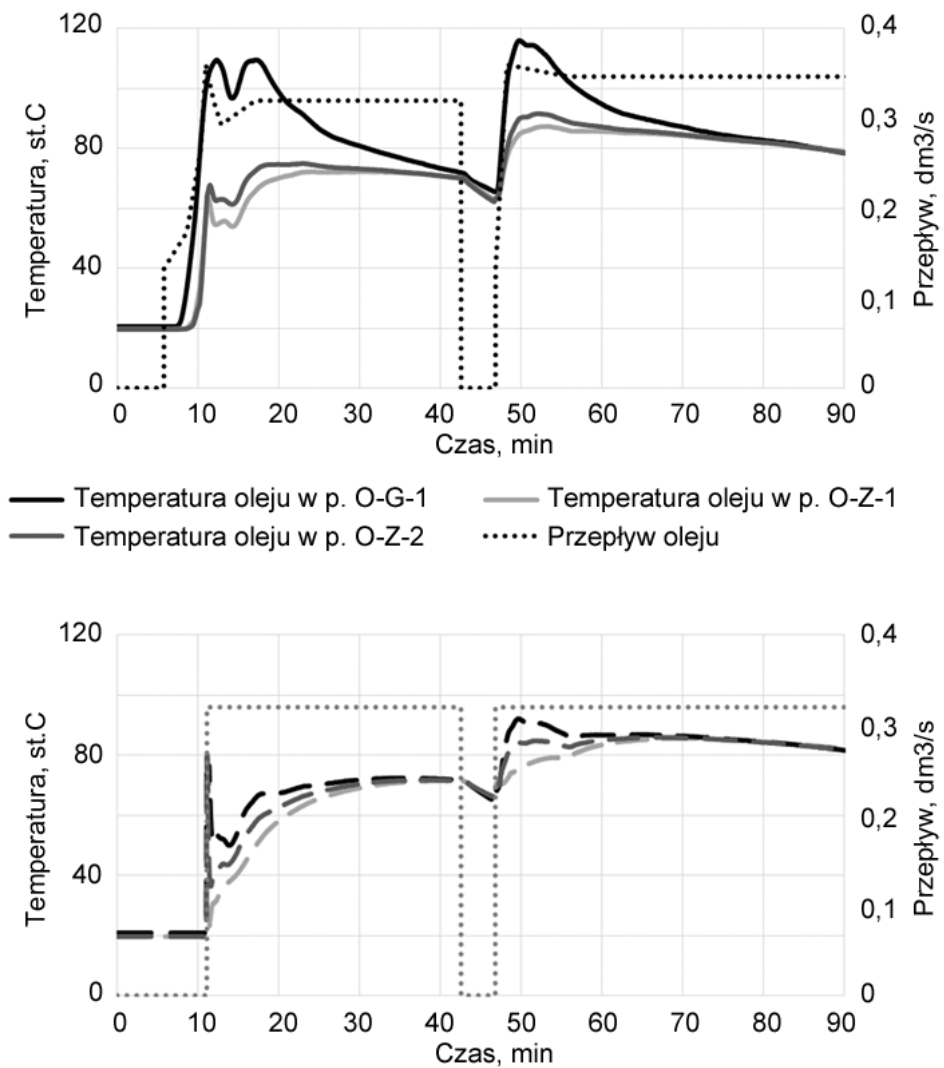

$\begin{array}{lll}\text { Temperatura wody w p. W-CH-1 } & \text { Temperatura wody w p. W-CH-2 } \\ \text { Temperatura wody w p. W-CH-3 } 3 \text {.... Przepływ wody chłodzącej }\end{array}$

Rys. 5. Przebiegi zmian temperatury oleju i wody chłodzącej w poszczególnych częściach układu

Fig. 5. Oil temperature and cooling water temperature changes in different parts of the cogeneration system 
Zmianom temperatury oleju i wody towarzyszyły odpowiadające im zmiany mocy w poszczególnych częściach układu. Najwyższa uzyskiwana moc obiegu olejowego i wodnego wynosiła w pikach odpowiednio ok. $45 \mathrm{~kW}$ i $35 \mathrm{~kW}$, natomiast w pozostałych momentach wyraźnie spadała. Przebieg zmian temperatury mocy w poszczególnych częściach systemu przedstawia rysunek 6.

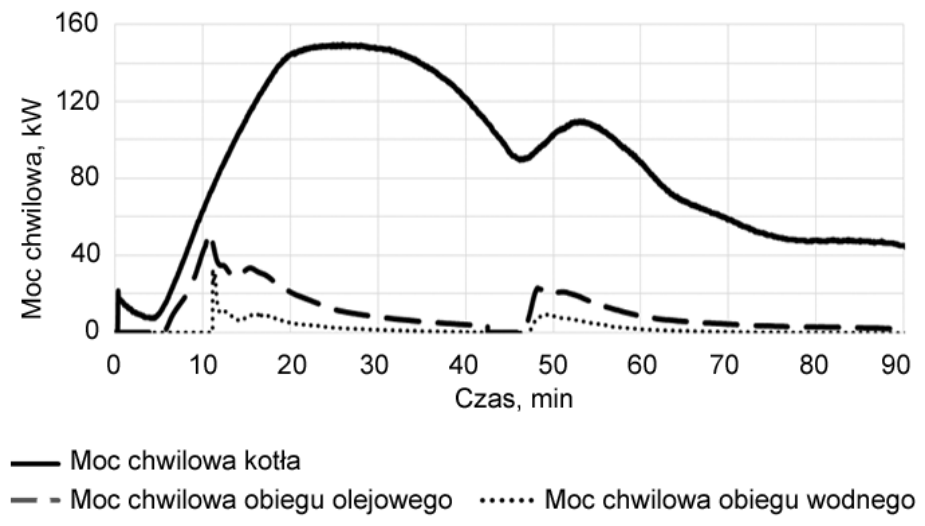

Rys. 6. Przebieg zmian mocy w poszczególnych częściach układu

Fig. 6. Power changes in different parts of the cogeneration system

\section{Podsumowanie}

Pierwsze badania, mimo iż prowadzone w fazie rozruchowej instalacji, potwierdzają zasadność dalszych prac badawczo-wdrożeniowych zmierzających do opracowania gotowego systemu kogeneracyjnego małej (mikro) skali, bazującego na wykorzystaniu kotła na biomasę oraz układu prądotwórczego z obiegiem organicznym Rankine'a (ORC).

Otrzymane do tej pory wyniki wykazują zróżnicowanie w zależności od trybu pracy układu. Najwyższą moc chwilową układu olejowego udało się uzyskać przy wykorzystaniu tylko jednego wymiennika ciepła typu JAD, natomiast najstabilniej w czasie układ zachowywał się przy połączeniu równoległym dwóch wymienników. Obserwacje te są jednakże w dużej mierze wynikiem sposobu prowadzenia procesu spalania, a praca poszczególnych części systemu wymaga wielu badań. Niemniej, moc uzyskiwana w układzie olejowym, stanowiąca w wybranych momentach 10 i więcej procent mocy cieplnej kotła sprawia, że spełnione są wstępne oczekiwania odnośnie pracy instalacji.

Niniejsza praca wykonana zostata $w$ ramach badań statutowych KZRE oraz projektu Bio-Eco-Matic. 


\section{Literatura}

[1] EU Energy, Transport and GHG Emissions Trends to 2050, Reference Scenario 2013, p. 47, http://ec.europa.eu [dostęp: 27 kwietnia 2014 r.].

[2] Sornek K., Tomski M., Filipowicz M.: Wykorzystanie biomasy w nowoczesnych, domowych systemach poligeneracyjnych, Zeszyty Naukowe Politechniki Rzeszowskiej nr 283. Seria: Budownictwo i Inżynieria Środowiska, 2012, s. 721-728.

[3] Sornek K., Szubel M., Goryl W., Bożek E., Filipowicz M.: Możliwość pozyskiwania i wykorzystania energii z biomasy, Przemysł Chemiczny, nr 12, 2014, s. 2071-2076.

\section{STUDY OF SELECTED OPERATING PARAMETERS OF BIOMASS BASED PROTYPE CHP SYSTEM}

\section{S u m m a r y}

This article presents possibilities of using small scale biomass boilers to construction combined heat and power systems dedicated to small and micro-scale solutions. Main goal of the research is to construct prototype installation using varied types of biomass with thermal capacity from 35 to $500 \mathrm{~kW}$. Experience gained during operation of this installation will be used to construct boiler dedicated to ORC system and to develop suitable control system for it. A proper operating of this system can indicate that biomass based CHP systems are good solution for small and micro CHP in distributed generation.

The main goal of research was to test the system in varied conditions: different amount of fuel, different controls and usage with few selected configurations of heat exchangers: single heat exchanger, two heat exchangers connected series and two heat exchangers connected parallel. The aim of such modification was to find optimal configuration of this installation. Research was performed in initial phase - water system instead ORC medium was used. Performed research shows that the highest power is obtained when only one heat exchanger is used, but the system is working more stable when two exchangers connected parallel are used. Moreover the research shows that oil temperatures is sufficient to generate steam in future ORC system. This initial research shows also that this project should be continued and further developed.

Keywords: renewable energy sources, biomass, cogeneration, distributed generation, micro energy sources

Przestano do redakcji: 17.02.2015 $\mathrm{r}$.

Przyjęto do druku: 22.06.2015 r.

DOI:10.7862/rb.2015.70 